
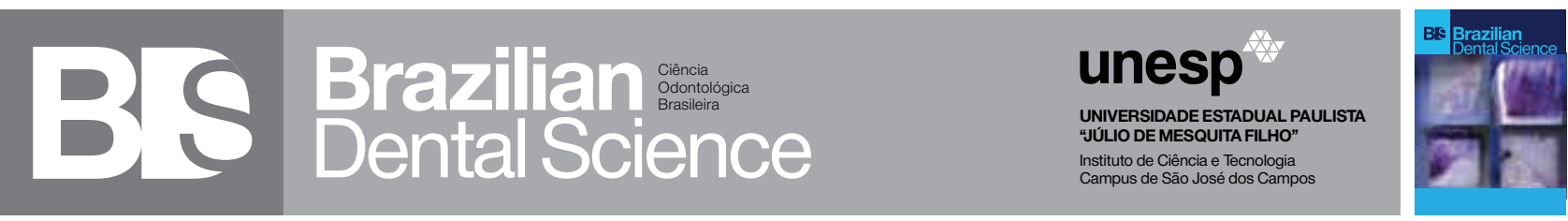

\title{
Analysis of flexural strength of a self cured acrylic resin used for fabricating provisional restorations with three different types of reinforcements
}

Análise da resistência à flexão de uma resina acrilica de ativação química utilizada para confecção de restaurações provisórias utilizando-se de três diferentes tipos de reforços

\author{
Karina Andrea Novaes OLIVIERI ${ }^{1}$, Ubirajara Viana COSTA ${ }^{1}$, Milton Edson MIRANDA ${ }^{1}$, Marcelo Lucchesi TEIXEIRA ${ }^{1}$, Johnson \\ Campideli FONSECA ${ }^{2}$ \\ 1 - São Leopoldo Mandic Dental Research Center - School of Dentistry - Campinas - SP - Brazil. \\ 2 - Center University of Lavras - School of Dentistry - Lavras - MG - Brazil.
}

\begin{abstract}
Objective: To evaluate the effect of three different types of reinforcements on the flexural strength of a chemically activated acrylic resin. Material and Methods: A Universal test machine EMIC 2000 was used at a speed of $5 \mathrm{~mm} / \mathrm{min}$., to evaluate the flexural strength of 40 test specimens $(65 \mathrm{~mm}$ x $10 \mathrm{~mm} \times 2.5$ $\mathrm{mm}$ ) fabricated of self cured activated acrylic resin, distributed into the following 4 groups: (1) control without reinforcement; (2) reinforced with $0.7 \mathrm{~mm}$ stainless steel orthodontic wire; (3) reinforced with Fibrex-lab ${ }^{\circledR}$ glass fiber and; (4) reinforced with Perma-Fiber ${ }^{\circledR}$ glass fiber. Results: The following flexural strength values were obtained: Group 1 80.60 MPa; Group 2 - 95.96 MPa; Group 3 - 105.70 $\mathrm{MPa}$; and Group 4 - $108.70 \mathrm{MPa}$. The analysis of variance $(\mathrm{p}<0.05)$ showed significant difference among the groups and the Tukey test showed that the control group presented the worst behavior, followed by reinforcement with metal wire, which showed statistically similar results to those of Group 3, with no difference shown between the fiber groups. Conclusion: Reinforcement with glass fibers present better flexural strength in comparison with the other methods.
\end{abstract}

\section{KEYWORDS}

Provisional dental restoration; Self curing of dental resin; Reinforcement; Strength.

\section{RESUMO}

Objetivo: Avaliar o efeito de três diferentes tipos de reforços na resistência à flexão de uma resina acrílica quimicamente ativada. Material e Métodos: A máquina de teste universal EMIC 2000 foi utilizada a uma velocidade de $5 \mathrm{~mm} / \mathrm{min}$, para avaliar a resistência à flexão de 40 espécimes de ensaio (65 x $10 \mathrm{~mm} \times 2,5 \mathrm{~mm}$ ) fabricados em resina acrílica quimicamente ativada, distribuídos em quatro grupos: (1) controle - sem reforço; (2) reforçado com 0,7 mm de aço inoxidável- fio ortodôntico; (3) reforçado com Fibrex-lab ® fibra de vidro e, (4) Perma-reforçado com fibra de vidro ${ }^{\circledR}$. Resultados: Os valores de resistência à flexão obtidos foram: Grupo 1- 80,60 MPa; Grupo 2- 95,96 MPa; Grupo 3- 105,70 MPa e Grupo 4-108,70 MPa. A análise de variância $(p<0,05)$ mostrou diferença significativa entre os grupos, e o teste de Tukey que o grupo de controle apresentou o pior comportamento, seguido do grupo de reforço com fios de metal, que mostrou resultados estatisticamente semelhantes aos do Grupo 3. Não houve diferença estatística entre os grupos de fibras. Conclusão: O reforço com fibras de vidro apresentam uma melhor resistência à flexão, em comparação com os outros métodos.

\section{PALAVRAS-CHAVE}

Restauração dentária temporária; Resina quimicamente ativada; Reforço; Resistência. 


\section{INTRODUCTION}

$\mathrm{T}$ he purpose of the provisional restorations is to protect the dentin-pulp complex in the prepared teeth; to evaluate and preserve the periodontal tissues; prevent movement of the abutment teeth; help to stabilize the teeth with mobility; provide the patient with adequate esthetics and phonetics, and promote comfort during masticatory function [1-3].

The longer the period of time of using these provisional teeth, the greater the durability required. Provisional restorations with inadequate mechanical resistance and marginal adaptation may lead to caries, tooth sensitivity, gingival inflammation, movement of the prepared tooth, in addition to constant fractures under occlusal loads. Failure of provisional restorations resulting from fractures or loss of marginal integrity, leads to great clinical inconvenience, capable of compromising the success of the definitive prosthesis [4,5].

Over the last 50 years, acrylic resin has been the material most used for provisional fixed restorations, thanks to its color stability, ease of processing, repair and pigmentation, in addition to its biocompatibility. Nevertheless, in spite of all these advantages, acrylic resins sometimes have insufficient mechanical properties to withstand the occlusal forces [2,68]. Fractures of these resins mainly occur due to flexural fatigue or failures resulting from impact $[7,9,10]$.

Various alternatives to the use of acrylic resins have been presented, such as: Epoxy resins, polycarbonates, polyethylenes and polyvinyl materials. Some increments have also been studied to reinforce poly-methylmethacrylate, such as metals; nylon; cross-linking agents; rubber polymers; corpuscles of ceramic, silica and sapphire; aluminum oxide, glass, polyethylene, aramid and carbon fibers [10-14].

The use of resin reinforcements has been described since the 1960s, when Grant \& Greener [16] proved the increase in resistance of these resins with the inclusion of aluminum fibers within them. Since then, many types and designs of metal reinforcements have been proposed. There are reports of wires of various diameters, plaited meshes and even orthodontic bands with the purpose of reinforcing resin $[1,11]$.

Researches have been directed towards developing techniques and materials that improve the quality and resistance of these fibers, and that allow the fabrication of provisional restorations of greater durability, quality and resistance. Thus, the aim of this study was to evaluate the effect of three different types of reinforcements on the flexural strength of a chemically activated acrylic resin.

\section{MATERIAL AND METHODS}

The present study was constituted of 4 groups $(\mathrm{n}=10)$, one being a control group without reinforcement, and three groups using some type of reinforcement (Chart 1).

Chart 1 - Description of the reinforcing material used and division of the groups

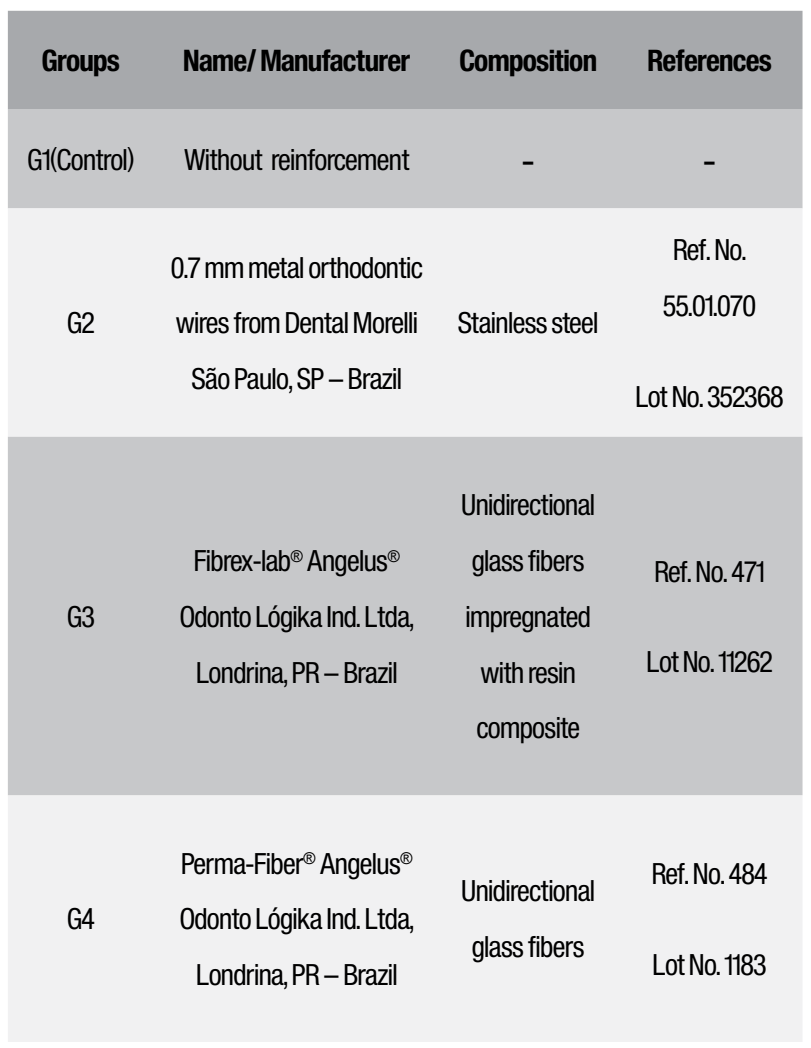


Firstly, stainless steel metal patterns were devised, in the shape of rectangular bars, measuring $67.0 \mathrm{~mm}$ long, $12.60 \mathrm{~mm}$ wide and $2.55 \mathrm{~mm}$ thick. These measurements were purposely larger than those demanded by the American Dental Association (ADA) Standard \#12 for flexural strength tests $(65.0 \mathrm{~mm}$ long, $10.0 \mathrm{~mm}$ wide and $2.5 \mathrm{~mm}$ thick), in order to allow correct finishing of the parts without compromising the final sizing values.

For including the metal patterns, plastic flasks especially developed for use in microwave ovens VIPI STG (VIPI Ind. com. Exp. e Imp. de Produtos Odontológicos Ltda - Pirassununga, Brazil) were used, filled with Type II plaster.

After this, three metal patterns were placed in an equidistant manner at a distance of approximately $10.0 \mathrm{~mm}$ between them. After the plaster had set completely, a thin layer of isolating material specifically for acrylic resin (Isocril, Dencril Produtos Odontológicos - Caieiras, Brazil) was applied. Next, there was a variation in the inclusion process, which consisted of using a condensation-polymerized silicone (Zetalabor, Zhermack - Italy), specifically prepared for the inclusion of parts in flasks. After concluding silicone polymerization, in approximately 30 min, the counter-flask was filled with type II plaster. After the plaster had set, the flasks were opened and the matrixes removed [15].

All the test specimens, with and without reinforcement, were prepared using self cured activated acrylic resin (Dencrilay Speed, Dencril Produtos Odontológicos - Caieiras, Brazil), shade No. 66. To fill the molds, the resins were proportioned and manipulated in accordance with the manufacturers' instructions, so that:

- For fabricating the test specimens without reinforcement for the Control Group, the resin was manipulated according to the manufacturer's instructions, in which $21 \mathrm{~g}$ of powder was incorporated into $7 \mathrm{ml}$ of liquid. After reaching the plastic stage, the material was pressed, and remained in the flask for a period of $2 \mathrm{~h}$ at room temperature before proceeding with deflasking.
- The reinforced test specimens were fabricated in a similar manner to those without reinforcement. The resin was equally proportioned and mixed, however, it was inserted in 2 stages. The reinforcement used was immersed in the respective monomer for $5 \mathrm{~min}$, and at the same time the resin was manipulated in the same way as previously described. Excess monomer was removed from the fibers or wires with paper towels. After the waiting the time required for the resin mixture to saturate, the first layer was inserted, so that half of the cavity, about $1.0 \mathrm{~mm}$, was filled. The reinforcement was centralized and placed in the lengthwise direction of the test specimen, and after this the remainder of the cavity was filled with a second layer of the same resin mixture. The material was pressed in the flask and remained this way for a period of $2 \mathrm{~h}$ at room temperature until the flask opening process was performed. After this period the flasks were opened and the test specimens obtained were placed in distilled water, while the finishing process was performed.

For finishing the parts a rotary sand paper Universal Polisher APL-4 (Arotec, Brazil) was used with 180 grit aluminum oxide abrasive papers. The test specimens were stored in refrigerated distilled water at $37^{\circ} \mathrm{C} \pm 2{ }^{\circ} \mathrm{C}$ and submitted to the flexural resistance test after a period of $48 \pm 2 \mathrm{~h}$, in accordance with the ADA specification \# 12.

To measure the flexural resistance, the three point bending test was performed, determined in megapascal (MPa) in a universal test machine (EMIC 2000) with a load of 200 kgf. The test specimens were positioned with a distance of $50 \mathrm{~mm}$ between the supports, with the load on the center of the test specimen at a speed of $5 \mathrm{~mm} / \mathrm{min}$, in strict accordance with the ADA standard \# 12.

Statistical power analysis showed the sample calculation $(n=10)$; data were submitted to the ANOVA one-way test ( $\mathrm{p}<0.05)$, and the differences among the groups were detected by the Tukey test $(\mathrm{p}<0.05)$. 


\section{RESULTS}

The mean values with the respective standard deviation data of flexural resistance are described in Table 1 . The data with reference to the comparison among the groups are described in Table 2.

Table 1 - Mean Flexural Resistance (MPa) and standard deviation (SD) for each group

\begin{tabular}{ccccc} 
& Group1 & Group2 & Group 3 & Group 4 \\
\hline Mean & 80.60 & 5.96 & 105.70 & 108.70 \\
\hline S.D & 6.14 & 7.57 & 6.98 & 6.45 \\
\hline
\end{tabular}

Table 2 - Tukey Test for flexural resistance values (MPa) for 4 groups

\begin{tabular}{|ccc|}
$\begin{array}{c}\text { Harmonic Mean of number of repetitions } \\
\text { Str): } \mathbf{1 0}\end{array}$ \\
\hline Treatments & Means & Test Results \\
\hline 1 & 80.60 & A \\
\hline 2 & 95.96 & B \\
\hline 3 & 105.70 & BC \\
\hline 4 & 108.69 & $\mathrm{C}$ \\
\hline
\end{tabular}

* different capital letters in the groups demonstrate significant differences at the level of $95 \%$, repetitions of letters demonstrate that there was no statistical difference among the groups.

\section{DISCUSSION}

The present research was conducted in accordance with the ADA specification \# 12, in compliance with the test specimen dimensions, storage conditions and performance of the test itself. According to the methodology determined by the ADA, the final dimensions of the test specimens would be established by cutting and finishing the original resin plate, which leads to resin heating, which could result in the conversion of residual monomer, and in variations in the properties of the material, which could lead to errors of interpretation. In this respect, the technique for processing the test specimens in this research was different, as the aim was to reduce the possibility of variables to the maximum possible extent [17].

The mean flexural resistance value for the Control Group without reinforcement found in this study (80.60 MPa), was similar to the values demonstrated by Koumjiam \& Nimmo [2], (76.81 MPa) and Vallittu et al. [5], (89.00 MPa). Nevertheless, these values are in contrast to the values described by Wang et al[7] (55.41 MPa) and Vallittu[19] (58.00 MPa).

The increase in flexural resistance as a result of the use of stainless steel wire inserted into PMMA - polymethylmethacrylate resin samples (19\% from Group 2 to Group 1) and glass fibers $(31 \%$ for Group 3 and $35 \%$ for Group 4 in comparison with the control group), $[12,13,20-22]$, who found a significant increase in flexural resistance in comparison with non reinforced PMMA resin samples.

When developing this research, an effort was made to simulate a clinical condition in which the resin is polymerized directly in the mouth at a body temperature of $37^{\circ} \mathrm{C}$, under minimal pressure. The flexural resistance results found in this study may, however, be lower than in studies in which resin polymerization was obtained under higher pressures. Ireland et al.[9], reported that the provisional restorations made directly in the oral cavity are polymerized under minimal pressure, and therefore, generate worse mechanical results due to the incorporation of air bubbles than those fabricated indirectly under higher pressures. Other techniques, such as polymerization under room temperature conditions $\left(23^{\circ} \mathrm{C}\right)$ [8], immersion of the resin in water or artificial saliva at different temperatures $[6,8,10]$, the use of greater or less pressure $[6,9]$ and the association of these variables $[1,6]$, have been proposed, and could notably influence the mechanical properties of the studied resin, which prevents an adequate systematization for comparison of the results.

Therefore, some of the variables related to the methodology of these studies may justify the differences in the comparison of the results. 
For example, various authors have argued that the greater the bond between the glass fibers and resin, the greater the flexural resistance of the samples [12,13,23,24]. Silane has been described as the material that effectively promotes this bond between PMMA and glass fiber $[12,13,18,24,25]$. For some authors, however, non-silanized glass fibers do not appear to exert any influence whatsoever on the resistance of PMMA polymers $[1,12,13]$. Other studies have shown, however, that an increase in the quantity of liquid monomer MMA (methamethylmethacrylate) around the fibers before they are incorporated to the final PMM resin mixture, appear to contribute to better wetting of the fibers and less incorporation of air bubbles $[20,25]$. In addition to this, Vallittu [5] observed that the use of a fluid mixture of PMMA-MMA does not result in optimum impregnation of fibers by PMMA resin. Based on these data from the literature, the choice was to immerse both reinforcements in MMA monomer, as several studies have reported that this method improves the bond between reinforcements of any type and the resin $[4,18,20,26]$. The immersion of fibers in MMA monomer is seen as the cause of the presence of air bubbles at the fiber-resin interface, resulting from greater polymerization shrinkage of the MMA monomer $(21 \%)$ in comparison with the PMMA polymer $(7 \%)$. This difference in polymerization shrinkage is associated with a smaller increase in flexural resistance, and therefore, the addition of a fluid mixture of PMMA-MMA is proposed, in preference to immersing the fiber in MMA monomer [24]. Thus, analysis and comparison of the results obtained with those found in the literature should be done very carefully, taking care not to arrive at unfounded conclusions, given some of the differences in the process of test specimen preparation among the various studies.

The environment, temperature and time during which the resin is stored immediately after it is polymerized has smaller effect on its mechanical characteristics. Koumjian \& Nimmo [2] found no differences in the flexural resistance of samples made of PMMA after storage in water at $37^{\circ} \mathrm{C}$ for seven days, when compared with those stored in a dry environment at $23{ }^{\circ} \mathrm{C}$ for the same period of time. Ireland et al. [9], observed no significant difference in flexural resistance and in the modulus of elasticity when resins were stored in water at $37^{\circ} \mathrm{C}$ for $24 \mathrm{~h}$ or 60 days. The storage of test specimens in water at $37^{\circ} \mathrm{C}$ for $48 \mathrm{~h}$, was therefore only relevant because it is the minimum period of time necessary for complete polymerization of the resin.

A higher concentration by weight of glass fibers should also be considered as a factor in the increase in flexural resistance and modulus of elasticity of PMMA resins [24]. Concentrations by weight as high as $21 \%$ to $45.4 \%$ for glass fibers have been associated with an increase in resistance and rigidity of these polymers when reinforced with these fibers [19,24,25,27]. This fact could explain the significant increase in flexural resistance with the unidirectional Fibrex-Lab $\AA$ and Perma fiber ${ }^{\circledR}$ fibers were used. This fiber is sold in the form of a long and relatively thick bundle that can be cut and/ or undone according to the clinical-laboratory situation, however, the manufacturer does not mention the minimum concentration, by weight or volume of this fiber that should be used $[28,29]$.

Ladha \& Shah [30] reported that the reinforcement of denture base resin with preimpregnated glass fibers may be a useful means of strengthening denture bases. Da Silva et al. [31] said that the addition of glass fiber did not increase the flexural strength however the use of a resin-based composite produced significant reinforcement.

It is understood that adequate fracture resistance is only one of the requisites of provisional restorations to guide the choice of material or technique. In spite of the limitations of laboratory techniques with regard to the reproduction of clinical situations, they are useful and necessary for comparing materials and techniques in controlled situations [10]. 
In accordance with the results of the present study, both the Fibrex-Lab® and PermaFiber ${ }^{\circledR}$ fibers can be used as reinforcement in provisional restorations with the purpose of preventing an unfavorable situation of fracturing the acrylic teeth. Thus, the technique for fabricating provisional restorations reinforced with fibers is interesting, as it is a simple and practical method, and promotes a significant increase in the resistance of provisional restorations, thereby improving their clinical behavior.

\section{CONCLUSION}

Within the methodology used in this research and the results obtained, it could be concluded that:

a) The groups reinforced with $0.7 \mathrm{~mm}$ stainless steel orthodontic wire, Fibrex-Lab and Perma-fiber glass fibers, presented higher flexural strength values in comparison with those obtained in the control group;

b) Among the groups evaluated, the one reinforced with Perma-Fiber glass fiber was that which presented the greater numerical values , however, without differing statistically from the group reinforced with Fibrex-Lab glass fiber.

\section{REFERENCES}

1. Henry PJ, Bishop BM, Purt RM. Fiber-reinforced plastics for ínterim restorations. Quintessence Dent Technol Yearbook. 1990/1991;14:110-23.

2. Koumjian $\mathrm{JH}$, Nimmo A. Evaluation of fracture resistance of resins used for provisional restorations. J prosthet Dent. 1990 Dec;64(6):654-7.

3. Powell DG, Nicholls JI, Youdelis RA, Strygler H. A comparison of wire-and Kevlar-reinforced provisional restorations. Int J Prosthodont. 1994 Jan-Feb;7(1):81-9.

4. Samadzadeh A, Kugel G, Hurley E, Aboushala A. Fracture strengths of provisional restorations reinforced with plasma-treated woven polyethylene fiber. J Prosthet Dent. 1997 Nov;78(5):447-50.

5. Vallittu PK. The effect of glass fiber reinforcement on the fracture resistance of a provisional fixed partial denture. J Prosthet Dent. 1998 Feb;79(2):125-30.

6. Donovan TE, Hurst RG, Campagni WV. Physical properties of acrylic polymerized by different techniques. J prosthet Dent.1985 $0 \mathrm{ct} ; 54(4): 522-4$

7. Wang RL, Moore BK, Goodacre CJ, Swartz ML, Andres CJ. A comparison of resin for fabricating provisional fixed restorations. Int J Prosthodont. 1989 Feb;2(2):173-84.
8. Ogawa T, Tanaka M, Koyano K. Effect of water temperature during polymerization on strength of autopolymerizing resin. J prosthet Dent. 2000 Aug;84(2):222-4.

9. Ireland MF, Dixon DL, Breeding LC, Ramp MH. In vitro mechanical property comparison of four resins used for fabrication of provisional fixed restorations. J prosthet Dent. 1998 Aug;80(2):15862.

10. Haselton DR, Diaz-Arnold AM, Vargas MA. Flexural strength of provisional crown and fixed partial denture resins. J Prosthet Dent. 2002 Feb;87(2):225-28.

11. Carroll CE, Von Fraunhofer JA. Wire reinforcement of acrylic resin prostheses. J Prosthet Dent. 1984 Nov;52(5):639-41.

12. Vallittu PK, Lassila VP. Reinforcement of acrylic resin denture base material with metal or fibre strengtheners. J Oral Rehabil. 1992 May;19(3):225-30.

13. Vallittu PK. Comparison of 2 different silane compounds used for improving adhesion between fibres and acrylic denture base material. J Oral Rehabil. 1993 Sep;20(5):533-9.

14. Bae JM, Kim KN, Hattori M, Hasegawa K, Yoshinari M, Kawada E, et al. The flexural properties of fiber-reinforced composite with light-polymerized polymer matrix. Int J Prosthodont. 2001 JanFeb;14(1):33-9.

15. Bastos LGC. Avaliação da resistência flexional, do módulo de elasticidade e do tipo de fratura de uma resina acrílica para restaurações provisórias - efeito de diversos reforços [dissertação]. Bauru: Faculdade de Odontologia de Bauru. Universidade de São Paulo; 2003.

16. Grant AA, Greener EH. Whisker reinforcement of polymethyl methacrylate denture base resins. Aust Dent J. 1967 Feb;12(1):2933.

17. Barboza DB, Souza RF, Lucas MG, Leles CR, Compagnoni MA. Resistência à flexão de resina acrílica polimerizada por energia de microondas. Cienc Odontol Bras. 2003;6(2):72-9.

18. Vallittu PK. Glass fiber reinforced in repaired acrylic resin removable dentures: preliminary results of a clinical study. Quintessence Int. 1997 Jan;28(1):39-44.

19. Vallittu PK. Flexural properties of acrylic resin polymers reinforced with unidirectional and woven glass fibers. J Prosthet Dent. 1999 Mar;81(3):318-26.

20. Vallittu PK. The effect of void space and polymerization time on transverse strength of acrylic-glass fibre composite. J Oral Rehabil. 1995 Apr;22(4):257-61.

21. Stipho HD. Effect of glass fiber reinforcement on some mechanical properties of autopolymerizing polymethyl methacrylate. $\mathrm{J}$ Prosthet Dent. 1998 May;79(5):580-4.

22. Nohrström TJ, Vallittu PK, Yli-Urpo A. The effect of placement and quantity of glass fibers on the fracture resistance on interim fixed partial dentures. Int J Prosthodont. 2000 Jan-Feb;13(1):72-8.

23. Uzun G, Hersek N, Tinçer T. Effect of five woven fiber reinforcements on the impact and transverse strength of a denture base resin. J Prosthet Dent. 1999 May;81(5):616-20.

24. Vallittu PK, Lassila VP, Lappalainen R. Acrylic resin-fiber composite - part I: the effect of fiber concentration on fracture resistance. $J$ Prosthet Dent. 1994 Jun;71(6):607-12.

25. Vallittu PK, Ruyter IE, Ekstrand K. Effect of water storage on the flexural properties of e-glass and silica fiber acrylic resin composite. Int J Prosthodont. 1998 Jul-Aug;11(4):340-50. 
26. Dixon DL, Breeding LC. The transverse strengths of three denture base resins reinforced with polyethylene fibers. J Prosthet Dent. 1992 Mar;67(3):417-19.

27. 27. Ladizesky NH, Pang MKM, Chow TW, Ward IM. Acrylic resins reinforced with woven highly drawn linear polyethylene fibres. 3. Mechanical properties and further aspects of denture construction. Aust Dent J. 1993 Jan; 38(1):28-38

28. 28. Narva KK, Lassila LV, Vallittu PK. The static strength and modulus of fiber reinforced denture base polymer. Dent Mat. 2005 May;21(5):421-8.

29. Obukuro M, Takahashi Y, Shimizu H. Effect of diameter of glass fibers on flexural properties of fiber-reinforced composites. Dent Mater J. 2008 Jul;27(4):541-8.
30. 29. Soares RG. Avaliação da resistência flexural, módulo de elasticidade, carga de ruptura e parâmetros de cor de resinas acrílicas utilizadas para restauracões provisórias com fibra de vidro [dissertação]. Ribeirão Preto: Faculdade de Odontologia de Ribeirão Preto. Universidade de São Paulo; 2009.

31. 30. Ladha K, Shah D. An in-vitro evaluation of the flexural strength of heat-polymerized poly (methyl methacrylate) denture resin reinforced with fibers.J Indian Prosthodont Soc. 2011 Dec;11(4):21520

32. 31. da Silva LH, de Castro HL, Tango RN, de Arruda Paes Júnior TJ, Kimpara ET. Evaluation of flexural resistance of a denture base acrylic resin reinforced with glass fiber and with composite resin. Eur J Prosthodont Restor Dent. 2010 Sep;18(3):107-10.

\section{Karina Andrea Novaes Olivieri} (Corresponding address)

Rua Octavio Conte, 161 - Bragança Paulista-SP CEP - 12919-401 